IRA-International Journal of Education \& Multidisciplinary Studies

ISSN 2455-2526; Vol.03, Issue 03 (2016)

Institute of Research Advances

http://research-advances.org/index.php/IJEMS

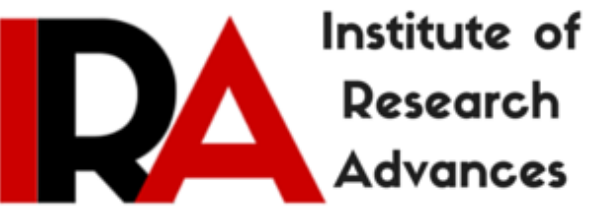

\title{
Meeting Me at Horizon: In Search of Life through Hermann Hesse's Siddhartha
}

\section{Dr. Indrani Singh Rai}

Associate Professor

Amity School of Languages

Amity University, Chhattisgarh, India.

DOI: $\underline{\text { http://dx.doi.org/10.21013/jems.v3.n3.p3 }}$

\section{How to cite this paper:}

Rai, D. (2016). Meeting Me at Horizon: In Search of Life through Hermann Hesse's Siddhartha. IRA International Journal of Education and Multidisciplinary Studies (ISSN 2455-2526), 3(3). doi:http://dx.doi.org/10.21013/jems.v3.n3.p3

(C) Institute of Research Advances

\section{(cc) EY-No}

This works is licensed under a Creative Commons Attribution-Non Commercial 4.0 International License subject to proper citation to the publication source of the work.

Disclaimer: The scholarly papers as reviewed and published by the Institute of Research Advances (IRA) are the views and opinions of their respective authors and are not the views or opinions of the IRA. The IRA disclaims of any harm or loss caused due to the published content to any party. 


\section{ABSTRACT}

There is an unending flow of life which enters and exists at its predetermined time. Very few may have tried to apprehend the purpose of life, endeavor to explore its existence in cosmos, attain tranquility and celestial bliss. In the luxurious peripheral phase, people may be busy with desire and aspiration but a shift from exterior to interior is indispensible to know the mystery of the universe. A voyage must be embarked on to arrive at the center to realize the true essence of life. This paper, through Hermann Hesse's stunning novel Siddhartha, tries to explore the quintessential existence of human being, the reason of this puppet show, ultimate goal of the journey and the path through which Nirvana can be attained. It's an endeavor to show how beautifully a German writer ignites the intellect and helps to know how the Transcendental Bliss be attained.

Key Words: Self, Polarities, Journey, Consciousness, Salvation

\section{Introduction:}

The wrings of Hermann Hesse, the German writer, have a deep and firm root in the Vedas, the Upanishads and in the Buddhism. In this contemporary worldly fringe, his writings compel to re-think and unveil the mystery of the 'Self', urge to make a shift from periphery to centre to 'Know Thyself'. His novel Siddharth is a true critique of life and it explores the intrinsic flow to reach 'Enlightened State. In the novel, an inexorable search for truth is exhibited for creating a harmonious bond with the world.

The novel revolves round Siddhartha, a sincere spiritual pilgrim, who is on a voyage due to his quest for spiritual enlightenment. He gains knowledge of his Brahmin custom and masters the skills of the Samanas and the teachings of Gotama, but all these seem inadequate for him because he has not found the path of enlightenment there. He refuses the explanations of religions as he is not satisfied with and he believes no leader or philosophy is beyond questioning. The truth for which Siddhartha and his friend Govinda search is a universal understanding of life. They both have an indispensable desire to comprehend their lives through spirituality and seek the 'Nirvana'. Nirvana, according to Siddhartha, leads to an ideal association with the world and is thus an end goal that each man seeks to arrive at.

'Nirvana', according to Buddhist notion means 'ultimately empty' (paramasunnya) or the 'highest emptiness' (aggasunnya). It means the Nirvana-Existent is empty of self because of the nonexistence of self' and specifies that both Conditioned Existents and the Unconditioned Existent are all empty of self because of the absence of a person to be classified as a self. It refers to a place (metaphorically), state or condition where there is no death, because there is also no birth, no coming into existence, nothing made by conditioning, and therefore no time. It is actually cut off the bonds of passion and hatred. According to Collins:

At enlightenment, constructive consciousness within the sequence ceases. At final nirvana constructed-consciousness is succeeded by timeless nirvana (which can be seen as a temporal event only from the conditioned, temporal point of view). That which replaces the constructed-consciousness of the sequence, temporally extended and variegated according to different lives, and that which supervenes on the destruction of "the conceit (that) "I am" (Imagery and Thought in Theraviida Buddhism 100-3)

It can be said that it is not nonexistence, and it is a timeless bliss. 
Siddhartha possesses an implausible measure of patience. His quest takes a lifetime to fulfill. He grows through consecutive spiritual explorations, experiences disappointment but continue until he reaches his goal. Siddhartha is the Sanskrit name of the Buddha which means 'he who achieves his goal.' derived from Sanskrit (siddha) 'accomplished' and (artha) 'goal'. The writer, through the growth of Siddhartha tries to indicate a path to enlightenment. Siddhartha discovers that enlightenment cannot be attained through preaches because it cannot be taught rather it comes from within. Siddhartha embarked on searching for illumination at the outset by looking for exterior assistance from structured belief in the form of Brahmins, Samanas, and Buddhists. But the exterior fails to quench his thrust. He leaves the Brahmins, the Samanas, Gotama, and the material enchantment and enthrallment because he feels discontented. His ultimate triumph to understand 'Nirvana' does not come from someone rendering the insight but in its place through an internal union to the river, which stands for the unending flow of the cosmos.

Siddhartha learned a lot when he was with the Samanas, many ways leading away from the self he learned to go. He went the way of self-denial by means of pain, through voluntary suffering and overcoming pain, hunger, thirst, tiredness. He went the way of self-denial by means of meditation, through imagining the mind to be void of all conceptions. These and other ways he learned to go, a thousand times he left his self, for hours and days he remained in the non-self. But though the ways led away from the self, their end nevertheless always led back to the self. (Siddhartha 38)

Life dwells in polarity - that is, in relationship to its opposite or polar energy and our level of connectivity in relation to it. The crucial split is the polarity between resistance to living our inner light and fully acceptance of our divinity. 'Are we the body or the dweller within the body?' This evident detachment to the source of our being is the very hazard that binds us from deliverance. Our mental constrictions sets certain parameters when the soul is eternal and without human periphery. The soul's unbounded liberty reflects the nascent of our human capability. The connection with the divine center is the substance of life. Siddhartha is conscious of these polarities. So in the first third of the book, he discards the material world. The Brahmins, Samanas, and Buddhists all sustain the faith that the material world is illusion only, or 'Maya'. It is the highest hurdle for a seeker to explore the spiritual truth. Siddhartha accepts this belief, and he denies his body entirely and centers his efforts on purifying his mind. But in the second third of the book, Siddhartha unpredictably rejects the saintly world and shits from interior to exterior or the material world. He gradually apprehends that inexorable web of life, desires, bodily love do not endow him with wisdom. Siddhartha, through his life exhibits other polar opposites as well. He has gone through time/timelessness and attachment/detachment, but his ultimate realization is that accepting one and rejecting the other cannot bring him the blissful mind or state.

Vasudeva is a simple ferryman who is projected in the novel as the serine guide who at last leads Siddhartha to illumination. Vasudeva's presence seems to transcend the physical world; he renders a divine energy always by unfolding his experiences and knowledge which he has learnt from the flowing river. He never teaches Siddhartha a complex truth-seeking credence but he unfurls the tranquil learning which he has learnt from the river and asks Siddhartha to get the essence of it. Vasudeva may be an external guide, but he never attempts to tell Siddhartha what the meaning of life is. Instead, he shows Siddhartha the way to identify the close unity between himself and the flow of the river, to listen to the river and introspect for an understanding of the message which the river renders. No teaching or preaching is provided by Vasudeva, he even does not articulate what the river will unfold, but when Siddhartha discloses his feeling of 
unification with the unending flow of the river, Vasudeva acknowledges the affinity of the perceived wisdom rendered by the universe.

The river plays the crucial role in Siddhartha's spiritual progression. He listens to the river whenever he has questions or doubts and with the passage of time, he reaches his divine destination. It's the game of time and destiny that Siddhartha achieves 'Nirvana' exactly that time when Vasudeva's time on the river and on earth comes to an end. Vasudeva, who has accurately and symbolically ferried Siddhartha to enlightenment, exits earth with Siddhartha taking over as ferryman. Vasudeva is Krishna, an incarnation of Vishnu, a strong force of Hindu Trinity means "he who lives in all thoughts, and who lives in all people." Vasudeva exists and will exist with innumerable Siddharthas always; He is the life force and anchor of human souls.

So the river in the novel is a symbol of two polarities of human life, the opposing banks stand for the divergence, and the river symbolizes the final unification of them. Siddhartha comes across long awaited illumination only when he comprehends 'Om', the unity of polarities. The concept of 'Om', which connotes the oneness, marks key moments of awakening for Siddhartha. He steps in transcendence when he is capable to accept the truth that at a point, everything is False and True and at the same moment, living and dead are same. All probabilities are cohesive and tied up with the spirit of the universe.

In the case of Govinda, the same conflict of exterior and interior has been portrayed. He sticks with the religious teachers for his wisdom, but returns back with empty hands because of this reliance on a peripheral justification, Govinda constantly fails to find Nirvana. He pleads Siddhartha to teach him the path to enlightenment. Siddhartha's outlook:

Seeking means to have a goal; but finding means to be free, to be receptive, to have no goal. You, $\mathrm{O}$ worthy one, are perhaps indeed a seeker, for in striving towards your goal, you do not see many things that are under your nose. (113)

It's no teaching but the awareness which brings Govinda the illumination. Siddhartha acts as a conduit for Govinda, as the river did for him. So, both the paths, interior and exterior have been shown by Hesse to attain tranquility but exterior path is completely abandoned because Nirvana comes from within.

The next quarry is that does love exist or indispensible in the life of a saint who is on his voyage to search and seek the meaning of life? Hesse tries to prove authentically in the novel the place of love in the growth of a saintly soul. Love appears in the life of Siddhartha with many names and relations and posses intricacies to the final triumph of Siddhartha's quest but Hesse explains the role of it in human life. Love exists between Siddhartha and his father, but Siddhartha rejects it leaving his father to follow the Samanas. Love in this juvenile stage limits Siddhartha's capability to understand divine wisdom and he abandons it. Siddhartha finds love in the form of compassion in Buddha but he rejects this love again because he realizes it as a part of teachings only that do not guide him to enlightenment. He learns the physical aspects of love through the proximity with Kamala; he understands the weight of love itself too but he is inept of giving and receiving true love at this stage. So he confiscates himself as he is not convinced and profited by the offerings of the world. Siddhartha feels love and is attached deeply with his son, but since love is an attachment to the world, it warns him. He is frightened that the love he feels for his son turns out to be a hurdle to get wisdom but he feels the intense pain of separation when his son leaves him behind.

...his face resembled another face, which he used to know and love and also fear. It resembled his father's face, the Brahmin. And he remembered how he, a long time ago, as a young man, had forced his father to let him go to the penitents, 
how he had bed his farewell to him, how he had gone and never come back. Had his father not also suffered the same pain for him, which he now suffered for his son? (174)

But the truth is enlightenment is not devoid of love. It may be excruciating but to attain transcendental illumination, it has to be felt and accepted.

There is a never ending flow of life. No death or birth truly is there in cosmos but in this peripheral platform, souls have to perform myriad character roles. In the eventful and aspiring life, sometimes silence is essential to understand self and the purpose of drama in which the role is played. S.B. Bhambar's remark is striking:

Each individual has to experience the truth, the reality. Hesse is of the view that if you want to experience the truth, then the truth must be within the framework of your body. Govinda, Siddhartha's friend, remains stagnate in spite of following the Buddha for many years because the truth was not within the framework of his body. (A Dualist Spiritual Journey pp.150-151)

Siddhartha had concluded with the realization that the wise Brahmans had already opened to him the most and best of their wisdom, that they had already filled his weighty vessel with their richness, and the vessel was not full, the spirit was not content, the soul was not calm so the heart was not satisfied. So he had a single goal to become empty, empty of thirst, empty of wishing, empty of dreams, empty of joy and sorrow. The circle is a spiral; a web, human being should move up, and ascend to upper level. Henry David Thoreau's observation is that "The unconsciousness of man is the consciousness of God" (The Writing of Henry David Thoreau 371)

\section{Conclusion:}

So, life can be understood through the odyssey of a simple man who spent his whole life in exploring the truth. What makes Siddhartha to reach a state of total contentment and serenity by means of a long and strenuous path? The secret is there in The Gita as development of each character is divided into three distinct stages: innocence, followed by knowledge ('sin'), which, collectively, leads to an elevated state of innocence convoyed by augmented awareness and consciousness. According to the Gita, the flow is from action to knowledge to wisdom. Thus Siddhartha's journey that begins with a restless search for perceiving the Self ends with the serene realization of the Self. There may be different ways for different people to reach God but the spiritual journey is primarily individual. It all depends on one's seeking spirit but unity of all sentient and insentient beings is the essence of Hesse's Siddhartha. Human being meets with himself at the fringe of known and unknown, in between dawn and dusk at horizon and then starts the voyage to seek truth and transcendental serenity.

\section{References:}

Bhambar, S.B. 2010. Hermann Hesse's Siddhartha - A Dualist Spiritual Journey. Language In India Volume 10: 3 March 2010 ISSN: 1930-2940

Collins, S. (1982) Selfless Persons: Imagery and Thought in Theraviida Buddhism. Cambridge University Press.

Hesse, Hermann. (2013) Siddhartha. New Delhi: Lexicon Books.

Henry David Thoreau. (1906) The Writing of Henry David Thoreau. New York: Houghton Mifflin. 